\title{
ЕТнОЛОГІЯ
}

УДК 392:392.12:477.86/.87

DOI https://doi.org/10.32838/2663-5984/2021/1.26

\section{Войтович Н.M.}

Львівський національний університет ветеринарної медицини та біотехнологій імені С.3. Гжицького

Денис I.3.

Національний лісотехнічний університет України

\section{ДЕМОНОЛОГІЧНІ МОТИВИ РОДИЛЬНОЇ ОБРЯДОВОСТІ БОЙКІВ}

У статті розглядається родильна обрядовість у контексті народних демонологічних вірувань; аналізуються ті демонологічні мотиви, які, за уявленнями украӥнців Бойківщинни, детермінували стан вагітної жінки, могли впливати на майбутнє життя дитини; детально описано ритуально-магічні дї, які оберігали як матір, так і немовля від потенційної шкоди «нчистої сили».

Методологія дослідження - системний підхід до вивчення традиційно-побутової культури з використанням загальнонаукових методів, насамперед систематизації та узагальнення. Для уточнення вже відомої інформації зі сфери родильних обрядів, розуміння символіки певних демонічних нашарувань, відстеження трансформаційних процесів у народних віруваннях проведено низку польових експедицій. Застосовуємо також метод пережитків та історико-порівняльного аналізу.

Наукова новизна розвідки - изе акцент на демонологічних аспектах сімейних обрядів на підставі введення у науковий обіг польових етнографічних матеріалів.

Висновки. Урбанізація, боротьба цүеркви із народними віруваннями, забобонами, вплив засобів масової інформачиї та сочіальних мереж, культурна і туристична політика держави завдають шкоди та вносять корективи у цюю архайчну ділянку народної культури бойків. Попри все остання порівняно добре зберіглася у зазначеному етнографічному районі, а окремі ї̈ аспекти мають давнє походження. Загалом изе стосується і родильної обрядовості, і народної демонології. Деякі вірування, уявлення, магічні рецепти є зовсім нераціональними у XXI столітті, проте окремі (наприклад, якнайшвидше здійснення обряду хрешення, давні способи захисту немовляти від «зуроків») можна зафіксувати і нині у процесі польових пошуків серед украӥнців Карпат, щзо може вказувати на раціональність їхнього застосування.

Ключові слова: народна демонологія, народна культура, родильна обрядовість, Бойківщзина, бойки.

Постановка проблеми. Нині, в добу незалежної України, актуальною є проблема збереження етнокультурної спадщини. Саме тому надзвичайно важливо досліджувати елементи традиційної культури, детально аналізувати усі їі складники, зокрема й «нижчу» міфологію. Актуалізація питань, пов'язаних із народною демонологією та їі осмисленням, є украй необхідною і 3 огляду на те, що сфера вірувань наповнена різними демонологічними мотивами та «присутня» в усіх елементах традиційно-побутового життя, зокрема у календарній, сімейній, родильній обрядовостях.
Аналіз останніх досліджень і публікацій. Перший опис традиційного життя українців Бойківщини належить перу Ігнація Любича-Червінського у відомій його праці “Okolica zadniestrska między Stryjem i Łomnicą”, де автор проаналізував обряди, пов'язані із хрестинами та їхнім святкуванням [19, с. 247-249].

На магічних моментах окремих вірувань бойків акцентував увагу Данило Лепкий. Йдеться про апотропейні засоби захисту дитяти від русалок та смерті загалом; переконання про пошук померлою дитиною хреста; ірраціональні методи лікування дитячих хвороб $[12 ; 10 ; 11]$. 
У спільній розвідці Яна Фальковського і Богдана Пашницького "Na pograniczu łemkowskobojkowskiem" побіжно проаналізовано низку магічних табу, які стосувалися вагітної жінки, породіллі, перелічено символічні предмети чи інгредієнти, які додавалися до першої купелі $[18$, c. $73-74]$.

Родильні обряди бойків є сферою наукового зацікавлення сучасних дослідників Романа Гузія та Лесі Горошко, які описують ті магічно-ритуальні дії під час родильної обрядовості, що побутували на Старосамбірщині [7].

Трансформаційні процеси, порівняльний аналіз традиційного й нового в елементах родильних звичаїв та обрядів Бойківщини здійснює київська дослідниця Зоряна Небесна [13]. Однак сучасних розвідок, які б акцентували увагу саме на демонологічному контексті родильної обрядовості бойків, на жаль, зовсім небагато.

Постановка завдання. Мета статті - показати присутність демонологічних мотивів у сфері родильної обрядовості; проаналізувати ті народні вірування, забобони, табу, які, за уявленнями горян, впливали на стан породіллі, майбутню долю новонародженої дитини; описати ритуально-магічні дії, які захищали як матір, так і дитину від негативного впливу «нечистої сили»; акцентувати увагу на тих магічних рецептах, які мають давнє світоглядне походження та практичне застосування навіть у XXI столітті.

Виклад основного матеріалу дослідження. Згідно із традиційними уявленнями українських горян час та обставини зачаття мали визначальний вплив на долю дитини. Бойки вірили, що діти, зачаті на Великдень, ставали вовкунами або ж «як ся дітина зробит на велике свято, то та дітина нечиста - опирь» [4, арк. 15].

Серед масиву південнослов'янських вірувань можна відшукати уявлення про демонів долі та навіть принесення ім жертви, зокрема, коли перше зістрижене дитяче волосся викидали на смітник (гній). Дослідник польської традиційної культури Адам Брюкнер суттєво доповнив їх тим, що спочатку слов'яни із такого волосся готували ритуальну страву - так звану «бабину кашу» для рожаниць, випрошуючи таким чином щасливе майбутне для новонародженої дитини [17, с. 171]. Такі сюжети характерні і для українців Бойківщини: «Баба-повитуха знала, що дітину чекає. Як ся дітина вродила, то якась душьи стойит під вікном і всьо бабі розказує про ту дітину». «Як уже відгуляли весілля, то дівка ся покриє. Як буде у вінци - буде ся віддавати. Як уже його поколисали, то ся повісит» [6, арк. 17].

Тут побутували уявлення про жіночих демонічних персонажів (повітруля, перелесниця), підгрунтям для формування яких було народження дітей із різними зовнішніми вадами, зокрема надмірно великими головами чи потворними обличчями. Саме це, за народними переконаннями, легітимізувало у сільській громаді ще XIX - початку $\mathrm{XX}$ століття аборти чи навіть дітовбивство. Польові матеріали свідчать, що різні фізичні відхилення новонародженого давали підстави уподібнювати його до представників демонологічного пантеону: «Лупирь, то вродилося таке рахітне, червоне було, росло хіба в голову» [2, арк. 6].

Варто зазначити, що й поведінка вагітної жінки регламентувалася чіткими магічними нормами. Сільське населення Українських Карпат вважало, що відмова вагітній у чому-небудь запрограмує нещасливу долю для іiї ще ненародженої дитини і вона може навіть стати жебрачкою [5, арк. 11]. Доля дитини, навіть обставини іiі смерті, у народному уявленні детермінувалися поведінкою вагітної. Бойки вірили, що майбутній матері заборонено тримати в руках мотузку, бо тоді їі дитину чекатиме доля повішеника [16, с. 180]. Очевидно, що труднощі материнства іноді штовхали жінок на аморальні вчинки (аборти, дітовбивства). Проте сільська громада їх частково виправдовувала, особливо, коли йшлося про порятунок села від голоду, неврожаю: «Жона вагітна має ся купати у прорубі, то дощ піде. Але казали, шо іiї дитина на воді має погибнути, не доживе свого віку, втопиться» [3, арк. 18].

Особливі магічні засоби захисту використовували мешканці Бойківщини і після народження дитини, на яку, як вірили, чекало чимало темних сил. Наприклад, здатністю зашкодити поглядом (врікати. - Авт.), особливо дитині, яка була ще нехрещеною, володіла «нечиста» жінка (у якої були регули. - Aвm.): «Споганити може жона дітину, коли «на ній є» [15, с. 485]. Коли ж дитина захворіє, то лікували хворобу яйцем, яке батько ніс опівночі у дупло верби, що росте на перехресті чотирьох доріг. На території Рожнятівського району Івано-Франківської області місію лікаря дитячих хвороб виконував представник однієї із найшанованіших і наймагічніших професій у селі - коваль [5, арк. 17].

Іноді завдавали шкоди чи визначали усе подальше життя людини чарівники, які вдавалися до чорної магії та використовували речі із померлої людини: «3 мертвого полотна тов нит- 
ков обв'язали мале дівча, аби до неї хіба мертві хлопці хотіли ся женити» [3, арк. 7]. «Був у нас в селі єден чоловік, шо вічно спав, бо хтось поставив із його сорочки, як він був дитинов, кусок у домовину мертвому» [2, арк. 20].

Як стверджував I. Кузів, під час процесу пологів ліжко породіллі на Бойківщині обмальовують освяченою крейдою, а в одвірку залишають встромлений ніж [9, с. 336]. Породілля завжди тримала біля себе залізні речі як оберіг від нечисті, а після того, як дитина народилася (особливо у першу ніч), хтось із родичів пильно оберігав, щоб їі часом не поміняли представники демонічних сил. Таких в уяві українських горян було багато, зокрема i вітерниия, яку бойки намагалися обманювати, поклавши у ліжко біля новонародженого макогін і спеленавши його [12, с. 269], адже навіть вислів «облизати макогін» означав «понести заслужену кару, піймати облизня» [14, с. 17].

Мотив підміни дітей характерний i для карпатської перелесниці. Демонологічні оповідки про останню зафіксовано польськими етнографами на Старосамбірщині у XIX ст. [20, с. 440-441]. Сучасний польовий матеріал також це підтверджує: «Малиньку дітину ссе. То треба прикладати то, шо дітина наробит, до грудий або котячку, або у шось вінчавне завити дітину, або тим вінчавним на вікні поробити ляльки» [4, арк. 14].

Загалом екскременти є поширеним обереговим засобом у демонологічній практиці, а використання ляльки є свідченням ритуально-магічної імітації, адже таким чином «перелесниця прийде, але буде ссати ті ляльки (замість дитини. - Aвm.) i потім уже не прийде» $[20$, с. 440]. Від небажаного приходу перелеснииі чи повітрулі бойки застосовували низку магічних способів: дитячі груди намащували екскрементами, прикладали залізні речі, зокрема й копійки [6, арк. 5].

Існував ще один цікавий ритуал для повернення своєї дитини: «Як на Великдень пекти паску, то слід ставити дітину вітерниці на лопату, класти її, ніби хочеш пекти ту дітину» [4, арк. 5]. Отже, пов'язаний він був із вогнем та осередком домашнього вогнища в оселі. Коли ж жіночим демонічним персонажам вдавалося викрасти та поміняти людську дитину на свою, то останню (обміняника) били: «Казали, що десь на печи клали огинь, яйце розбивали тим однолітком (прутиком ліщини, який виріс за один рік. - Авт.), дірочки такі робили ним, воду туди лляли. Потім вона приходила і питала: «Що ти робиш?» «Їсти варю». «А де ти виділа, шоби в яйци їсти варити?» - «А де ти виділа, аби літавиця мою дітину забрала?» - і вертала дітину» [4, арк. 17].

Такі демонологічні сюжети не $є$ унікальними, адже у них простежуємо використання апотропейного засобу від «нечистих» покійників, який викликає ефект подиву. «Нечистих» покійників бойки дуже боялися, вважали навіть, що часта смерть дітей спричинена їхнім похованням у «чистій» землі, тобто в межах кладовища. Тому дуже часто горяни наважувалися на радикальні дії, зокрема виривали хрест із могили померлого [4, арк. 19].

Традиційно важливе магічне значення мав процес першого грудного вигодовування, оскільки він населенням Українських Карпат вважався першою ініціацією, після якої дитина, скуштувавши материнського молока, ставала грішною, втрачала «чистоту» [2, арк. 2].

Давніми за походженням $є$ уявлення українців Карпат про душі померлих дітей і їхню демонічну персоніфікацію. Бойки вважали, що недоношена чи страчена дитина може стати хованцем / годованцем - одним із типів домашнього духа, уявлення про якого характерні для карпатобалканської зони. Підтвердженням цієї гіпотези $є$ записані нами на території Бойківщини такі його назви: Олекса, Федьо, Юрко, Іванцьо, Панько, Андрейко. Ілюструє цю версію і матеріал із Гуцульщини: «Щоб багатство розводилося, жінка має свою першу дитину закопати живою на тому грунті, на котрому хочеться, щоб багатство розводилось» $[8$, с. 189]. Це дає підставу гіпотетично припускати, що демонім «хованець» первісно пов'язаний із недоношеними або страченими дітьми, яких осоромлені покритки, побоюючись громадського осуду та покарання, часто закопували під порогом хати, тобто ховали від інших людей [1, арк. 6].

Водночас у бойківській системі демонічних вірувань існує низка демонічних персонажів, генезис яких безпосередньо пов'язаний із душами померлих дітей. Це мавки, майки, потерчата, недонощі, спокуса, покуса, змітки, зишля, нехристи, змітча, страдчики. Причиною їхнього перетворення на шкідливих демонічних істот була неможливість перетину кордону, який вів до потойбічного світу. Бойки також вірили, що вбивство матір'ю дитини / аборт - великий гріх, наслідки якого відіб'ються не лише на безпосередній виконавиці цього вчинку, а й на усій сільській громаді, оскільки покаранням за нього буде тотальний град, який призведе до неврожаю та голоду [3, арк. 9].

Відповідно до етнографічних матеріалів, сюжетів міфів і легенд, народних уявлень жінка, 
яка зробила аборт, буде покарана за цей гріх. Проте вона це відчує лише на «тому» світі, адже ій доведеться їсти своїх ненароджених убитих дітей [3, арк. 5]. Часто таку жінку уподібнюють до свині, яка їсть своїх поросят, або до квочки. Проте це не відлякувало майбутніх матерів, більше того - траплялися випадки, коли вони за допомогою чарівників хотіли з'ясувати посмертну долю страченої дитини: «Хотіла одна ввидіти свою таку дітину. Пішла до ворожбита: «Йди на Йордан під церков, лиш кожух натягни навиворіт». А іï дітинка йде із відрами і каже: «То ти мене й тут найшла». То добре, що була в кожусі, бо рано дивітьсі, а кожух весь подертий. То ї так тоті діти обшарпали» [5, арк. 8].

Висновки. Урбанізація, боротьба церкви із народними віруваннями, забобонами, вплив засо- бів масової інформації та соціальних мереж, культурна i туристична політика держави завдають шкоди та вносять певні корективи у цю архаїчну ділянку народної культури бойків. Та попри все остання порівняно добре зберіглася у зазначеному етнографічному районі, а окремі iї аспекти мають давнє походження. Стосується це і родильної обрядовості, і народної демонології.

Деякі вірування, уявлення, магічні рецепти $\epsilon$ зовсім нераціональними у XXI столітті, проте окремі (наприклад, якнайшвидше здійснення обряду хрещення, давні способи захисту немовляти від «уроків») можна зафіксувати і нині під час польових пошуків на території Українських Карпат, що свідчить про актуальність і раціональність їхнього застосування для мешканців досліджуваного регіону.

\section{Список літератури:}

1. Архів Львівського національного університету імені Івана Франка. Ф. 119. Оп. 17. Спр. 208-Е. Арк. 1-8.

2. Архів Львівського національного університету імені Івана Франка. Ф. 119. Оп. 17. Спр. 209-Е. Арк. 1-30.

3. Архів Львівського національного університету імені Івана Франка. Ф. 119. Оп. 17. Спр. 210-Е. Арк. 1-23.

4. Архів Львівського національного університету імені Івана Франка. Ф. 119. Оп. 17. Спр. 211-Е. Арк. 1-19.

5. Архів Львівського національного університету імені Івана Франка. Ф. 119. Оп. 17. Спр. 215-Е. Арк. 1-17.

6. Архів Львівського національного університету імені Івана Франка. Ф. 119. Оп. 17. Спр. 216-Е. Арк. 1-19.

7. Гузій Р., Горошко Л. Родильні звичаї та обряди на Старосамбірщині (за матеріалами польових досліджень). Народознавчі зошити. 2010. № 5/6. С. 611-617.

8. Кісь О. Жінка у традиційній українській культурі (друга половина XIX - початок XX ст.) : монографія. Львів, 2012. 287 с.

9. Кузів І. Житє-бутє, звичаї і обичаї горского народу. Зоря. 1889. № 20. С. 336-337.

10. Лепкий Д. Деякі вірування про дитину. Зоря. 1886. № 15/16. С. 269-270.

11. Лепкий Д. Обряд хрещення малих дітей на Руси та деякі вірування і забобони людови. Зоря. 1887. № 18. С. 297-298.

12. Лепкій Д. Про народні забобони. Зоря. 1884. № 13. С. 105-107.

13. Небесна 3. Звичаї при народженні дитини на Бойківщині. Динаміка змін в обрядовості XX XXI століть. Народна творчість та етнографія. 2010. № 6. С. 40-46.

14. Сов’як П. Мак у віруваннях та обрядовості бойків. Літопис Бойківщзини. 2002. № 1. С. 16-18.

15. Толстая М.Н. Из материалов карпатских экспедиций. Восточнославянский этнолингвистический сборник. Исследования и материальь. Москва : Индрик, 2001. С. 477-495.

16. Франко І. Людові вірування на Підгір'ю. Етнотрафічний збірник. 1898. Вип. V. С. 160-218.

17. Brückner A. Mitologia stowiańska i polska. Warszawa, 1980. $383 \mathrm{~s}$.

18. Falkowski J., Pasznycki B. Na pograniczu temkowsko-bojkowskiem: Zarys etnograficzny. Lwów, 1935. $128 \mathrm{~s}$

19. Lubicz-Czerwińsky J.I. Okolica zadniestrska między Stryjiem i Łomnica. Czyli opis ziemi, dawnych klęsk lub odmian tej okolicy. Lwów, 1811. $281 \mathrm{~s}$.

20. Strzetelska-Grynbergowa Z. (1899). Staromiejskie. Ziemia i ludność. Lwów, 676 s. 


\section{Voitovych N.M., Denys I.Z. DEMONOLOGICAL MOTIVES OF THE BIRTHING RITUALISM OF THE BOYKOS}

The aim of the research is to show the presence of demonological motives in the field of the birthing rituals; to analyze those people's beliefs, prejudices, taboos, which, according to the highlanders, influenced the state of pregnant women, the future fate of a newborn child, etc., describe ritual-magic actions that defended both from the negative effects of "evil spirits".

The methodological basis of the study is the principle of historicism, a systematic approach to the studying of phenomena and objects of traditional culture using general scientific methods, primarily systematization and generalization. In order to expand the source base, the field ethnographic expeditions were conducted. Field ethnographic method was used to expand the factual basis of research, updating it with new colorful details, clarifying the content and nature of the individual elements of demonological layer of the birthing ceremonies, observing the transformation of traditional beliefs. Distributed in ethnology methods of relics and historical-comparative method were used in the process of research.

The scientific novelty of the study is to broaden the knowledge about the demonological aspect of birthing ritualism by attracting new factual data into scientific circulation, especially field ethnographic materials.

Conclusion. Despite significant obstacles (urbanization processes, the impact of the church, the media, the imperfect state policy in the field of culture, tourism, etc.) investigated area of traditional culture and the chosen ethnographic method have good perspectives. There are grounds for this, in particular, the relatively well-preserved ethnocultural heritage of the local population, the ancient origin of many elements of the birthing rituals and the system of demonological beliefs of the Boykos in general. It is concluded that most beliefs, taboos and ordinances have an irrational mythological basis. However, some of them (such as the necessity for early ritual of christening, methods of protection against evil eye etc.) are prevalent among the highlanders of the Carpathians today, indicating their rationality.

Key words: folk demonology, folk culture, birthing ritualism, Boykivshchyna, the Boykos. 